\title{
No evidence of West Nile virus infection among Polish patients with encephalitis
}

\author{
JOANNA JABEONSKKA ${ }^{1}$, MARTA POPIEL ${ }^{2}$, IWONA BUKOWSKA-OŚKO', KAROL PERLEJEWSKI', \\ KAMILA CARABALLO CORTÉS ${ }^{2}$, ANDRZEJ HORBAN $N^{1}$, URSZULA DEMKOW', TOMASZ LASKUS ${ }^{2}$, \\ MAREK RADKOWSKI
}

${ }^{1}$ Municipal Hospital for Infectious Diseases, Warsaw, Poland

${ }^{2}$ Department of Immunopathology of Infectious and Parasitic Diseases, Warsaw Medical University, Warsaw, Poland

${ }^{3}$ Department of Laboratory Medicine and Clinical Immunology of Developmental Age, Medical University of Warsaw, Warsaw, Poland

\begin{abstract}
West Nile virus (WNV) infection usually causes mild febrile illness, but in a small proportion of patients it can lead to encephalitis. Epidemiological studies of WNV indicate fast spread of infection worldwide and in Europe, but there have been no comprehensive studies of WNV infection among encephalitis patients in Poland.

Here we present the results of WNV RNA and anti-WNV testing in serum and cerebrospinal fluid (CSF) samples in 80 patients with the clinical diagnosis of viral encephalitis. WNV RNA was not detected in any of the analyzed samples. Anti-WNV IgG and IgM were not present in CSF in any of the investigated patients, but anti-WNV IgM were unexpectedly detected in serum of 14 subjects. The latter represented false positive results are probably related to cross reactivity of antibodies. Although there was no evidence of WNV infection in any of our patients, epidemiological situation in the neighbouring countries warrants vigilance and appropriate measures, including introduction of specific diagnostic tools into clinical practice, seem necessary.
\end{abstract}

Key words: West Nile virus, neuroinfection, emerging infection, Flaviviridae.

(Cent Eur J Immunol 2016; 41 (4): 383-385)

\section{Introduction}

West Nile virus (WNV) was first described in 1937 in Uganda as an etiological agent of mild febrile illness [1]. Although most WNV infections in humans are asymptomatic or present with benign flu-like syndrome only, up to $1 \%$ of infected subjects progress to more severe disease [2-4]. Clinically overt infection is more frequent among elderly or immunocompromised patients and in subjects with co-existing chronic medical conditions like diabetes or renal failure $[5,6]$. WNV can be responsible for a considerable proportion of encephalitis and meningitis cases, $3-19 \%$ of which have fatal outcome $[1,7,8]$.

Epidemiological studies of WNV indicate fast and extensive spread and there are well documented cases of WNV infection in Romania (Bucharest 1996), Russia (Volgograd 1999), USA (New York City 1999), and Israel (2000) [9-11]. After the initial appearance of WNV in New York, WNV-related encephalitis cases were reported in different areas of the USA, as well as in Mexico, and Canada, Central and South America [12, 13], and WNV is currently recognized as one of the most important causes of viral encephalitis worldwide [1].
Encephalitis is the most common form of WNV neuroinvasion (50-71\%), followed by meningitis (15-35\%) and acute flaccid paralysis $[14,15]$. However, Guillain-Barré syndrome and brachial plexus palsy were also reported to be associated with this virus [16-18]. Of note, a significant proportion of patients recovering from the infection develop mental and physical sequelae [19]. Similarly to other Flaviviridae family members, WNV infection may persist for many years, although its consequences remain currently unclear [20].

Until now there have been no comprehensive studies of WNV infection among encephalitis patients in Poland as previous reports analyzed either very small groups of patients with meningitis or employed serodiagnostic screening only $[21,22]$. Here we present the results of WNV-RNA and anti-WNV testing in serum and cerebrospinal fluid samples (CSF) in a large group of patients with clinical diagnosis of viral encephalitis.

\section{Material and methods}

\section{Patients}

Eighty patients (42 men, 38 women) diagnosed as having encephalitis and hospitalized in recent years in the

Correspondence: Iwona Bukowska-Ośko, Department of Immunopathology of Infectious and Parasitic Diseases,

Medical University, Pawińskiego 3 C, 02-106 Warsaw, Poland, e-mail: ibukowska@wum.edu.pl

Submitted: 16.09.2016; Accepted: 26.10.2016 
Clinic of Infectious Diseases for Adults, Warsaw Medical University, were included in the study. The most common complaints were headache $(51.3 \%)$ and fever (43.8\%). At admission $20 \%$ of patients had decreased consciousness, $18.8 \%$ had meningeal signs and $20 \%$ had focal neurological signs. In only one case the course of encephalitis was fatal.

\section{Anti-WNV IgM and IgG analysis}

CSF and serum samples for all patients were tested for anti-WNV IgM and IgG class by commercially available kits (anti-West Nile Virus IgM \& IgG ELISA; Euroimmun, Lubeck, Germany) following procedure recommended by the manufacturer.

\section{WNV RNA detection}

Total RNA was extracted from serum and CSF samples by modified Chomczynski method employing Trizol reagent (Invitrogen, Carlsbad, USA). The obtained RNA was subjected to reverse transcription with random hexamers (Invitrogen, Carlsbad, USA) followed by amplification of viral 5'UTR region with primers (forward) 5'-AGTAGTTCGCCTGTGTGAGC-3' and (reverse) 5'-GCCCTCCTGGTTTCTTAGA-3'. The PCR run was performed using LightCycler FastStart DNA Master SYBR Green I (Roche Diagnostics, Switzerland) employing LightCycler 2.0 (Roche Diagnostics, Switzerland). Each of the 50 cycles consisted of $95^{\circ} \mathrm{C}(30 \mathrm{~s}), 57^{\circ} \mathrm{C}(5 \mathrm{~s})$, and $72^{\circ} \mathrm{C}$ $(30 \mathrm{~s})$, and fluorescence measurement was at $85^{\circ} \mathrm{C}(1 \mathrm{~s})$.

Table 1. Clinical and laboratory characteristics of patients with encephalitis $(n=80)$

\begin{tabular}{lc}
\hline Characteristics & \\
\hline Age (years; mean \pm SD) & $42.78 \pm 16.12$ \\
\hline Gender & $42(52.5 \%)$ \\
\hline Male, $n(\%)$ & $38(47.5 \%)$ \\
\hline Female, $n(\%)$ & $35(43.8)$ \\
\hline Major complaints & $41(51.3)$ \\
\hline Fever, $n(\%)$ & $16(20.0)$ \\
\hline Headache, $n(\%)$ & $13(16.3)$ \\
\hline At admission & $15(18.8)$ \\
\hline Decreased consciousness, $n(\%)$ & $16(20.0)$ \\
\hline Seizures, $n(\%)$ & $82.34 \pm 172.14$ \\
\hline Meningeal signs, $n(\%)$ & $0.74 \pm 0.56$ \\
\hline Focal neurological signs, $n(\%)$ & $3.68 \pm 1.12$ \\
\hline CSF analysis & \\
\hline Cytosis (in $1 \mu l)$, mean \pm SD & \\
\hline Proteins $(g / l)$, mean \pm SD & \\
\hline Glucose $(m m o l / l)$, mean $\pm \mathrm{SD}$ & \\
\hline
\end{tabular}

The positive control samples consisted of commercially available WNV AmpliRun West Nile Virus RNA (Vircell S.L., Grenada, Spain) containing 12.500-20.000 WNV copies/1 ml. Using dilutions of the above standard we found that it was able to detect 8-13 viral copies per reaction.

\section{Results}

The results of clinical and laboratory analysis are presented in Table 1.

Neither WNV RNA nor anti-WNV IgG were detected in any of the CSF or serum samples. However, while antiWNV IgM were not present in CSF they were detected in serum in 14 subjects.

\section{Discussion}

Viral neuroinfections transmitted by vectors represent a rising health problem worldwide. In Poland, the dominant form of vector-transmitted neuroinfection is tick borne encephalitis virus (TBEV), which was long confined to defined endemic regions, but now is seen throughout the country [23].

The presence of WNV infection was reported in such European countries as Greece, France, Romania, Hungary, Italy, Portugal and Spain, as well as in Poland's direct neighbours: the Czech Republic, Slovakia, Belarus and Ukraine [1]. Moreover, 12 out of 46 vectors capable of transmitting WNV (most prominently Culex pipiens) are common in Central and Eastern Europe and are also present in Poland [24]. Climate warming extends the habitat range of transmitting mosquitos as well as the duration of their seasonal activity [25].

West Nile Virus infection clearly represents a threat to Poland as it is already well-established in Europe including Poland's immediate neighbours. In support of the presence of WNV in Poland come reports on the detection of antiWNV-specific IgM in a patient suffering from fever of unknown etiology [24] and the detection of anti-WNV in a significant proportion of wild birds as well as in horses $[26,27]$.

Surprisingly, WNV RNA was not detected in any of our 80 encephalitis patients neither in serum nor in CSF. At the same time, 14 patients were anti-WNV IgM positive in serum. These findings are not necessarily discrepant, because the diagnostic relevance of serological screening for WNV infection is severely limited by the common antigenic cross-reactivity, which often leads to false positive results [28]. Thus, the immune response directed against viral envelope (E) protein can also be reactive against more conserved among large Flaviviridae family membrane and non-structural proteins [29].

Further support for the lack of WNV infection in Poland comes from a large study of wild birds, in which no 
WNV RNA was found in any of over 2000 birds tested [27]. Nevertheless, this epidemiological situation may rapidly change because WNV is well established in Europe and the vectors capable of transmitting infection are locally present.

In conclusion, WNV RNA was not found in any of the 80 encephalitis patients studied. However, the epidemiological situation in the neighbouring countries warrants vigilance and appropriate measures, including introduction of specific diagnostic tools into clinical practice, as well as constant monitoring of birds and mosquitoes, seem prudent.

This study was supported by Polish National Science Center (NCN), grant No. N/N401/646940, grant No. DEC2013/11/N/NZ6/00961 and Fundacja Rozwoju Nauki w Szpitalu Zakaźnym w Warszawie.

\section{References}

1. Chancey C, Grinev A, Volkova E, et al. (2015): The global ecology and epidemiology of West Nile virus. Biomed Res Int 2015: 376230.

2. Sejvar JJ (2014): Clinical manifestations and outcomes of West Nile virus infection. Viruses 6: 606-623.

3. Bode AV, Sejvar JJ, Pape WJ, et al. (2006): West Nile virus disease: a descriptive study of 228 patients hospitalized in a 4-county region of Colorado in 2003. Clin Infect Dis 42: 1234-1240.

4. Carson PJ, Borchardt SM, Custer B, et al. (2012): Neuroinvasive disease and West Nile virus infection, North Dakota, USA, 1999-2008. Emerg Infect Dis 18: 684-686.

5. Nash D, Mostashari F, Fine A, et al. (2001): The outbreak of West Nile virus infection in the New York City area in 1999. N Engl J Med 344: 1807-1814.

6. Patnaik JL, Harmon H, Vogt RL (2006): Follow-up of 2003 human West Nile virus infections, Denver, Colorado. Emerg Infect Dis 12: 1129-1131.

7. Kopel E, Amitai Z, Bin H, et al. (2011): Surveillance of West Nile virus disease, Tel Aviv district, Israel, 2005 to 2010. Euro Surveill 16.

8. Pepperell C, Rau N, Krajden S, et al. (2003): West Nile virus infection in 2002: morbidity and mortality among patients admitted to hospital in southcentral Ontario. CMAJ 168: 13991405.

9. Tsai TF, Popovici F, Cernescu C, et al. (1998): West Nile encephalitis epidemic in southeastern Romania. Lancet 352: 767-771.

10. Platonov AE, Shipulin GA, Shipulina OY, et al. (2001): Outbreak of West Nile virus infection, Volgograd Region, Russia, 1999. Emerg Infect Dis 7: 128-132.

11. Weinberger M, Pitlik SD, Gandacu D, et al. (2001): West Nile fever outbreak, Israel, 2000: epidemiologic aspects. Emerg Infect Dis 7: 686-691.

12. Lanciotti RS, Ebel GD, Deubel V, et al. (2002): Complete genome sequences and phylogenetic analysis of West Nile virus strains isolated from the United States, Europe, and the Middle East. Virology 298: 96-105.
13. May FJ, Davis CT, Tesh RB, et al. (2001): Phylogeography of West Nile virus: from the cradle of evolution in Africa to Eurasia, Australia, and the Americas. J Virol 85: 2964-2974.

14. Davis LE, DeBiasi R, Goade DE, et al. (2006): West Nile virus neuroinvasive disease. Ann Neurol 60: 286-300.

15. Petersen LR, Marfin AA. (2002): West Nile virus: a primer for the clinician. Ann Intern Med 137: 173-179.

16. Sejvar JJ, Haddad MB, Tierney BC, et al. (2003): Neurologic manifestations and outcome of West Nile virus infection. JAMA 290: 511-515.

17. Ahmed S, Libman R, Wesson K, et al. (2000): Guillain-Barre syndrome: An unusual presentation of West Nile virus infection. Neurology 55: 144-146.

18. Almhanna K, Palanichamy N, Sharma M, et al. (2003): Unilateral brachial plexopathy associated with West Nile virus meningoencephalitis. Clin Infect Dis 36: 1629-1630.

19. Loeb M, Hanna S, Nicolle L, et al. (2008): Prognosis after West Nile virus infection. Ann Intern Med 149: 232-241.

20. Murray K, Walker C, Herrington E, et al. (2010): Persistent infection with West Nile virus years after initial infection. J Infect Dis 201: 2-4.

21. Czupryna P, Niczyporuk J, Samorek-Salamonowicz E, et al. (2014): Detection of West Nile Virus RNA in patients with meningitis in Podlaskie Province. Przegl Epidemiol 68: 1720, 109-111.

22. Kondrusik M, Ferenczi E, Zajkowska J, et al. (2007): [The evaluation of serum presence of antibodies reacting with West Nile Fever virus (WNV) antigens among inhabitants from Podlaskie and Swietokrzyskie region]. Przegl Epidemiol 61: 409-416.

23. Amicizia D, Domnich A, Panatto D, et al. (2013): Epidemiology of tick-borne encephalitis (TBE) in Europe and its prevention by available vaccines. Hum Vaccin Immunother 9: $1163-1171$

24. Hermanowska-Szpakowicz T, Grygorczuk S, Kondrusik M, et al. (2006): Infections caused by West Nile virus. Przegl Epidemiol 60: 93-98.

25. Kubica-Biernat B, Kruminis-Lozowska W, Stanczak J, et al. (2009): A study on the occurrence of West Nile virus in mosquitoes (Diptera: Culicidae) on the selected areas in Poland. Wiad Parazytol 55: 259-263.

26. Niczyporuk JS, Samorek-Salamonowicz E, Lecollinet S, et al. (2015): Occurrence of West Nile virus antibodies in wild birds, horses, and humans in Poland. Biomed Res Int 2015: 234181.

27. Niczyporuk JS, Samorek-Salamonowicz E, Mizak WK (2011): The survey of wild birds for West Nile virus in Poland. Pol J Vet Sci 14: 573-577.

28. Sambri V, Capobianchi MR, Cavrini F, et al. (2013): Diagnosis of west nile virus human infections: overview and proposal of diagnostic protocols considering the results of external quality assessment studies. Viruses. 5: 2329-2348.

29. Zou S, Foster GA, Dodd RY, et al. (2010): West Nile fever characteristics among viremic persons identified through blood donor screening. J Infect Dis 202: 1354-1361. 